\title{
ANALISIS PEMECAHAN MASALAH TRIGONOMETRI SISWA SMK PEMESINAN
}

\author{
Liknin Nugraheni ${ }^{1)}$, Sri Rahayu ${ }^{2}$, dan Nur Fathonah ${ }^{3)}$ \\ 1,2,3 Dosen Pendidikan Matematika, Fakultas Keguruan dan Ilmu Pendidikan, Universitas PGRI Adi Buana \\ Surabaya, Jawa Timur Indonesia \\ Email: ${ }^{1}$ liknin@unipasby.ac.id
}

\begin{abstract}
Abstrak
Alasan penyebab sulitnya pemecahan masalah trigonometri oleh siswa SMK Pemesinan dapat ditinjau dari faktor siswa dalam meyelesaikan pemecahan masalah trigometri. Sehingga penting untuk melakukan analisis kesalahan yang telah dilakukan oleh siswa dalam pemecahan masalah trigometri tersebut. Adapun kesalahan yang dianalisis meliputi letak dan jenis serta faktor penyebab kesalahan yang dilakukan siswa dalam menyelesaikan pemecahan masalah trigometri. Masalah trigonometri khususnya dan meningkatkan hasil belajar matematika pada umumnya. Penelitian ini dilaksanakan di 3 (tiga) SMK Jurusan Pemesinan yakni SMKN 1 Jetis Mojokerto, SMK Nada Mojokerto, dan SMK Krian 1 Sidoarjo. Hasil dari penelitian ini, menunjukkan bahwa kesalahan yang dilakukan oleh Siswa SMK Pemesinan yang berkemampuan tinggi, sedang, rendah dan bergaya kognitif field dependent lebih banyak daripada Siswa SMK Pemesinan yang berkemampuan tinggi, sedang, rendah dan bergaya kognitif field independent ditinjau dari letak dan jenis kesalahannya. Sementara faktor penyebab terjadinya kesalahan yang dilakukan oleh Siswa SMK Pemesinan baik yang berkemampuan tinggi, sedang, atupun rendah dan bergaya kognitif field dependent ataupun field independent secara umum adalah faktor internal yang diakibatkan oleh kemampuan intelektual, dan kondisi kognitif dari Subjek.
\end{abstract}

Kata Kunci: Pemecahan Masalah, Trigonometri, SMK Pemesinan

\begin{abstract}
The difficulty in solving trigonometric problems of Vocational high School students at mechanical department can be seen from the factors of solving trigometry problems. Thus, it is important to analyze their errors in solving these problems. The errors include the location, type and factors that cause errors in solving trigometric problems. When the errors are recognized, we can determine alternative solutions to improve understanding of trigonometric problem solving in particular and mathematics learning outcomes in general. This research was conducted in 3 Machanical Departments, namely vocational high school 1 Jetis Mojokerto, vocational high school Nada Mojokerto, and vocational high school 1 Krian Sidoarjo. The results of this study showed that the field-dependent cognitive style students' errors were categorized as high, medium, low which was higher than field-independent cognitive tyle students in terms of the location and type of errors. While the factors that cause errors made by Mechanical department Students in vocational school were both high, medium, and low and field dependent or field independent cognitive style in general were internal factors caused by individual intellectual ability, and cognitive conditions.
\end{abstract}

Keywords: Problem Solving, Trigonometry, Machining Vocational School 


\section{PENDAHULUAN}

Pemecahan masalah matematika merupakan sesuatu yang banyak menjadi pusat perhatian di dalam kurikulum 2013 akhir-akhir ini. Banyak anak Indonesia yang mengalami kesulitan dalam pemecahan masalah matematika. Berdasarkan studi pendahuluan yang dilakukan peneliti di 3 SMK Pemesinan di Jawa Timur Indonesia, diperoleh informasi bahwa hanya $15 \%$ siswa SMK Pemesinan yang mampu menyelesaikan pemecahan masalah matematika khususnya trigonometri dengan baik. Untuk mengatasi permasalahan tersebut dan untuk mengetahui alasan yang menyebabkan rendahnya pemahaman pemecahan masalah trigonometri, maka perlu dilakukan analisis kesalahan yang dilakukan oleh Siswa SMK Pemesinan.

Beberapa penelitian menunjukan bahwa gaya kognitif merupakan suatu hal yang sangat penting dalam belajar. Dengan mengetahui gaya kognitif pebelajar, maka dapat diketahui cara yang tepat untuk dilakukan Guru ketika mengajar konsep matematika khususnya trigonometri pada individu yang memiliki gaya kognitif tertentu. Gaya kognitif yang digunakan dalam penelitian ini adalah gaya kognitif field dependent dan field independent.

Siswa dengan gaya kognitif field dependent adalah siswa yang susah untuk memisahkan item-item suatu obyek dari bentuk aslinya. Siswa yang memiliki gaya kognitif field independent adalah Siswa yang mampu mengabstraksikan elemen-elemen dari konteknya, mereka cenderung lebih analitik dan cenderung menggunakan pendekatan pemecahan masalah dengan cara lebih bersifat analitik.

Witkin, dkk. (1971) menyatakan bahwa, gaya kognitif merupakan suatu karakteristik yang tercermin dari setiap individu dan karakteristik tersebut dapat dipengaruhi oleh dua factor, yaitu : factor yang berkaitan dengan pengaruh rangsangan dari luar dan factor yang berkaitan dengan pengaruh personal individu. Yang dimaksud dengan faktor rangsangan dari luar adalah dominan yang cukup mempengaruhi masalah kejiwaan, seperti lingkungan pendidikan, lingkungan keluarga, dan lingkungan masyarakat. Hal ini sejalan dengan pendapat Dunn dan Dunn (dalam Lourdusamy, 1994) bahwa gaya kognitif dapat dipengaruhi oleh lima faktor, yaitu: lingkungan, social, emosi, fisiologi, dan psikologi.

Berdasarkan beberapa penelitian, selain gaya kognitif aspek perbedaan kemampuan siswa juga sangat berpengaruh terhadap kemampuan pemecahan masalah matematika. Pemacahan masalah didefinisikan sebagai usaha mencari jalan keluar dari suatu kesulitan untuk mencapai tujuan yang tidak dengan sengera dapat dicapai (Polya, 1973). Sedangkan Cooney dkk. (1975) mengemukakan bahwa pemecahan masalah sebagai proses penerimaan masalah dan berusaha menyelesaikan masalah itu. Pemecahan masalah merupakan perwujudan dari suatu aktivitas mental yang terdiri dari bermacammacam ketrampilan dan tindakan kognitif yang dimaksudkan untuk mendapatkan solusi yang benar (Kirkley, 2003). Sehingga pemecahan masalah antara seseorang dengan yang lainnya dimungkinkan berbeda.

Tahap pemecahan masalah yang dilakukan dalam penelitian ini, merujuk pada pendapat Polya. Tahapan pemecahan masalah Polya yaitu mulai dari (1) tadap memahami masalah, (2) membuat rencana pemecahan masalah, (3) melaksanakan rencana pemecahan masalah, (4) melihat kembali hasil pemecahan masalah. Sementara aspek kemampuan dalam penelitian ini adalah dipilih siswa SMK 
Pemesinan yang berkemampuan tinggi, sedang, dan rendah.

Alasan penyebab sulitnya pemecahan masalah trigonometri oleh siswa SMK Pemesinan dapat ditinjau dari faktor siswa dalam meyelesaikan pemecahan masalah trigometri. Sehingga penting untuk melakukan analisis kesalahan yang telah dilakukan oleh siswa SMK Pemesinan dalam pemecahan masalah trigometri tersebut. Adapun kesalahan yang dianalisis meliputi letak, jenis, dan faktor penyebab kesalahan yang dilakukan siswa SMK Pemesinan dalam menyelesaikan pemecahan masalah trigometri. Setelah mengetahui letak dan jenis kesalahan serta faktor penyebab kesalahan yang dilakukan siswa SMK Pemesinan dalam menyelesaikan pemecahan masalah trigometri kita dapat menentukan alternatif pemecahannya. Sehingga diharapkan dengan melakukan analisis kesalahan kita dapat meningkatkan pemahaman pemecahan masalah trigonometri khususnya dan meningkatkan hasil belajar matematika bagi siswa SMK Pemesinan pada umumnya.

\section{METODE PENELITIAN}

Jenis penelitian yang digunakan adalah penelitian deskriptif, karena dalam penelitian ini mendeskripsikan letak dan jenis serta faktor penyebab kesalahan siswa dalam menyelesaikan pemecahan masalah trigometri. Sedangkan pendekatan yang digunakan dalam penelitian ini adalah pendekatan kualitatif karena data yang dikumpulkan dan dipaparkan dalam bentuk kata-kata yang dirangkai dalam sebuah kalimat, bukannya berupa angka atau nilai.

Subjek Penelitian ini adalah siswa SMK Pemesinan di Jawa Timur Indonesia dengan Kriteria siswa kelompok berkemampuan tinggi bergaya kognitif field dependent dan field independent, siswa kelompok berkemampuan sedang yang bergaya kognitif field dependent dan field independent, serta siswa kelompok berkemampuan rendah yang bergaya kognitif field dependent dan field independent.

Selain peneliti sebagai instrument utama dalam penelitian ini dibutuhkan instrument lain yaitu seperti intrumen tes kemampuan matematika (TKM), tugas pemecahan masalah (TPM), tes GEFT, dan pedoman wawancara. Proses pengumpulan data dalam penelitian ini akan digunakan teknik pemberian tes dan wawancara, untuk mengetahui letak, jenis, dan factor penyebab kesalahan yang dilakukan subjek penelitian. Letak kesalahan dalam penelitian ini dilihat dari kesalahan yang dilakukan subjek pada sa'at pemecahan masalah sesuai dengan pentahan Polya. Jenis kesalahan yang dirujuk dalam penelitian ini, mengacu pada jenisjenis kesalahan yang dikemukakan oleh Sudjadi, yaitu jenis kesalahan fakta, konsep, operasi, dan prinsip. Factor penyebab kesalahan yang dilihat dalam penelitian ini terkait dengan factor internal. Analisis data dimulai sejak persiapan penelitian sampai dengan setelah proses pengumpulan data selesai. Dalam penelitian ini teknik menganalisa data dilakukan melalui 4 tahap, yaitu: kategorisasi data, reduksi data, penyajian data, penarikan kesimpulan.

\section{HASIL DAN PEMBAHASAN}

\subsection{Hasil}

Subjek dari penelitian ini adalah Siswa SMK Pemesinan di Jawa Timur Indonesia. Pemilihan Subjek penelitian diawali dengan pemberian TKM. Hasil pekerjaan TKM Siswa dinyatakan dalam bentuk skor, kemudian hasilnya akan dikategorsasikan. Subjek dikatakan berkemampuan tinggi, jika memperoleh skor $>87$, subjek dikategorikan berkemampuan sedang jika memperoleh nilai lebih besar dari 67 dan kurang dari 87, subjek 
dikategorikan berkemampuan rendah jika memperoleh nilai dibawah 67 .

Setelah diperoleh siswa yang berkemampuan tinggi, sedang, dan rendah, maka langkah selanjutnya adalah siswa yang berkemampuan tinggi, sedang, dan rendah yang terpilih diberikan tes GEFT. Pemberian tes GEFT, hasil tes GEFT yang dilakukan oleh siswa dinilai berdasarkan acuan yang dikembangkan oleh Witkin, yaitu Siswa yang memperoleh skor 0-9 pada bagian 2 dan 3 digolongkan dalam kelompok gaya kognitf field dependent (FD) sedangkan siswa yang memperoleh skor 10-18 digolongkan dalam kelompok gaya kognitf field independent (FI).
Untuk menentukan subjek penelitian perlu dilakukan tes GEFT sebanyak 3 sampai 5 kali, agar subjek yang terpilih memang benar-benar sesuai dengan gaya kognitifnya. Berdasarkan distribusi hasil kemampuan matematika dan gaya kognitif dan berdasarkan pertimbangan guru serta nilai rapot dari siswa SMK Pemesinan tersebut, maka dipilih 6 subjek penelitian yang memiliki kemampuan tinggi, sedang, dan rendah serta bergaya kognitif field dependent (FD) dan bergaya kognitf field independent (FI). Adapun karakteristik dari subjek penelitian yang meliputi inisial, kemampuan matematika, gaya kognitif, dan kodenya disajikan dalam Table .1 berikut.

Tabel .1 Subjek Penelitian dengan Karakteristik dan Kodenya

\begin{tabular}{cccccccccc}
\hline \multirow{2}{*}{$\begin{array}{c}\text { Inisial } \\
\text { Subjek }\end{array}$} & \multicolumn{2}{c}{$\begin{array}{c}\text { Kemampuan } \\
\text { Matematika }\end{array}$} & \multicolumn{3}{c}{$\begin{array}{c}\text { Gaya Kognitif Field } \\
\text { Independent }\end{array}$} & \multicolumn{2}{c}{$\begin{array}{c}\text { Gaya Kognitif Field } \\
\text { Dependent (FD) }\end{array}$} & \multicolumn{2}{c}{$\begin{array}{c}\text { Kode } \\
\text { Subjek }\end{array}$} \\
\cline { 2 - 9 } & Skor & Kategori & Tes-1 & Tes-2 & Tes-3 & Tes-1 & Tes-2 & Tes-3 & \\
\hline SDC & 30 & Rendah & - & - & - & 2 & 3 & 4 & S1 \\
\hline MFP & 30 & Rendah & 14 & 14 & 15 & - & - & - & S2 \\
\hline MHR & 80 & Sedang & - & - & - & 7 & 8 & 9 & S3 \\
\hline RAP & 80 & Sedang & 14 & 15 & 16 & - & - & - & S4 \\
\hline FRM & 95 & Tinggi & - & - & - & 6 & 7 & 6 & S5 \\
\hline AMA & 96 & Tinggi & 12 & 13 & 14 & - & - & - & S6 \\
\hline
\end{tabular}

Berdasarkan analisis dan hasil penelitian, maka untuk mengetahui letak, jenis, dan faktor penyebab kesalahan dalam pemecahan masalah trigonometri yang dilakukan subjek berdasarkan perbedaan kemampuan dan gaya kognitif secara umum dapat kita lihat pada Tabel .2 sebagai berikut.

Tabel .2 : Gambaran Umum Analisis Kesalahan Subjek Berdasarkan Perbedaan Kemampuan Dan Gaya Kognitif.

\begin{tabular}{|c|c|c|c|c|c|c|c|c|c|c|}
\hline \multirow{3}{*}{$\begin{array}{c}\text { Kemam } \\
\text { puan }\end{array}$} & \multicolumn{10}{|c|}{ Perbedaan Gaya Kognitif } \\
\hline & \multicolumn{5}{|c|}{ Field Dependent } & \multicolumn{5}{|c|}{ Field Independent } \\
\hline & $\begin{array}{l}\text { Letak } \\
\text { kesalaha } \\
\text { n pada } \\
\text { tahap }\end{array}$ & $\begin{array}{c}\text { Jenis } \\
\text { kesala } \\
\text { han }\end{array}$ & $\begin{array}{c}\text { Keterlaks } \\
\text { anaan }\end{array}$ & $\begin{array}{c}\text { Facto } \\
r \\
\text { penye } \\
\text { bab }\end{array}$ & $\begin{array}{c}\text { Alasan } \\
\text { kesalaha } \\
\mathrm{n}\end{array}$ & $\begin{array}{c}\text { Letak } \\
\text { kesalaha } \\
\mathrm{n}\end{array}$ & $\begin{array}{c}\text { Jenis } \\
\text { kesala } \\
\text { han }\end{array}$ & $\begin{array}{c}\text { Keterlaks } \\
\text { anaan }\end{array}$ & $\begin{array}{c}\text { Factor } \\
\text { Penye } \\
\text { bab }\end{array}$ & $\begin{array}{c}\text { Alasan } \\
\text { kesalaha } \\
\mathrm{n}\end{array}$ \\
\hline & \multirow{3}{*}{$\begin{array}{l}\text { Pemaha } \\
\text { man } \\
\text { masalah }\end{array}$} & Fakta & - & & - & \multirow{3}{*}{$\begin{array}{l}\text { Pemaha } \\
\text { man } \\
\text { masalah }\end{array}$} & Fakta & - & & - \\
\hline & & $\begin{array}{l}\text { Konse } \\
\mathrm{p}\end{array}$ & - & & - & & $\begin{array}{l}\text { Konse } \\
\mathrm{p}\end{array}$ & - & & - \\
\hline & & $\begin{array}{l}\text { Opera } \\
\text { si }\end{array}$ & - & & - & & $\begin{array}{l}\text { Opera } \\
\text { si }\end{array}$ & - & & - \\
\hline
\end{tabular}


WAHANA

e-ISSN 2654-4954, p-ISSN 0853-4403

Volume 71, Nomor 2, 1 Desember 2019

\begin{tabular}{|c|c|c|c|c|c|c|c|c|c|c|}
\hline \multirow{7}{*}{$\begin{array}{c}\text { Kemam } \\
\text { puan }\end{array}$} & \multicolumn{10}{|c|}{ Perbedaan Gaya Kognitif } \\
\hline & \multicolumn{5}{|c|}{ Field Dependent } & \multicolumn{5}{|c|}{ Field Independent } \\
\hline & $\begin{array}{l}\text { Letak } \\
\text { kesalaha } \\
\text { n pada } \\
\text { tahap }\end{array}$ & $\begin{array}{c}\text { Jenis } \\
\text { kesala } \\
\text { han }\end{array}$ & $\begin{array}{c}\text { Keterlaks } \\
\text { anaan }\end{array}$ & $\begin{array}{c}\text { Facto } \\
r \\
\text { penye } \\
\text { bab }\end{array}$ & $\begin{array}{c}\text { Alasan } \\
\text { kesalaha } \\
\text { n }\end{array}$ & $\begin{array}{c}\text { Letak } \\
\text { kesalaha } \\
\text { n }\end{array}$ & $\begin{array}{c}\text { Jenis } \\
\text { kesala } \\
\text { han }\end{array}$ & $\begin{array}{c}\text { Keterlaks } \\
\text { anaan }\end{array}$ & $\begin{array}{c}\text { Factor } \\
\text { Penye } \\
\text { bab }\end{array}$ & $\begin{array}{c}\text { Alasan } \\
\text { kesalaha } \\
\text { n }\end{array}$ \\
\hline & & Prinsi & - & & - & & Prinsi & - & & - \\
\hline & & $\mathrm{p}$ & & & & & $\mathrm{p}$ & & & \\
\hline & Merenca & Fakta & - & & - & Merenca & Fakta & - & & - \\
\hline & nakan & Konse & - & & - & nakan & Konse & - & & - \\
\hline \multirow[t]{19}{*}{ Tinggi } & pemecah & $\mathrm{p}$ & & Intern & & pemecah & $\mathrm{p}$ & & Intern & \\
\hline & $\begin{array}{l}\text { an } \\
\text { masalah }\end{array}$ & $\begin{array}{l}\text { Opera } \\
\text { si }\end{array}$ & - & $a l$ & - & $\begin{array}{l}\text { an } \\
\text { masalah }\end{array}$ & $\begin{array}{l}\text { Opera } \\
\text { si }\end{array}$ & - & $a l$ & - \\
\hline & & Prinsi & $\sqrt{ }$ & & Gspl \& & & Prinsi & - & & - \\
\hline & & $\mathrm{p}$ & & & $\begin{array}{c}\text { Trigono } \\
\text { metri }\end{array}$ & & $\mathrm{p}$ & & & \\
\hline & Melaksa & Fakta & - & & & Melaksa & Fakta & - & & - \\
\hline & nakan & Konse & - & & & nakan & Konse & - & & - \\
\hline & rencana & $\mathrm{p}$ & & & & rencana & $\mathrm{p}$ & & & \\
\hline & $\begin{array}{l}\text { pemecah } \\
\text { an }\end{array}$ & $\begin{array}{l}\text { Opera } \\
\text { si }\end{array}$ & - & & & $\begin{array}{l}\text { pemecah } \\
\text { an }\end{array}$ & $\begin{array}{l}\text { Opera } \\
\text { si }\end{array}$ & - & & - \\
\hline & masalah & $\begin{array}{l}\text { Prinsi } \\
\mathrm{p}\end{array}$ & $\sqrt{ }$ & & $\begin{array}{c}\text { Gspl \& } \\
\text { Trigono } \\
\text { metri }\end{array}$ & masalah & $\begin{array}{l}\text { Prinsi } \\
\mathrm{p}\end{array}$ & - & & - \\
\hline & Melihat & Fakta & - & & - & Melihat & Fakta & - & & - \\
\hline & kembali & Konse & - & & - & kembali & Konse & - & & - \\
\hline & hasil & $\mathrm{p}$ & & & & hasil & $\mathrm{p}$ & & & \\
\hline & $\begin{array}{l}\text { pemecah } \\
\text { an }\end{array}$ & $\begin{array}{l}\text { Opera } \\
\text { si }\end{array}$ & - & & - & $\begin{array}{l}\text { pemecah } \\
\text { an }\end{array}$ & $\begin{array}{l}\text { Opera } \\
\text { si }\end{array}$ & - & & - \\
\hline & masalah & $\begin{array}{l}\text { Prinsi } \\
\mathrm{p}\end{array}$ & $\sqrt{ }$ & & $\begin{array}{c}\text { Gspl \& } \\
\text { Trigono } \\
\text { metri }\end{array}$ & masalah & $\begin{array}{l}\text { Prinsi } \\
\mathrm{p}\end{array}$ & - & & - \\
\hline & $\begin{array}{l}\text { Pemaha } \\
\text { man } \\
\text { masalah }\end{array}$ & Fakta & $\sqrt{ }$ & \multirow{9}{*}{$\begin{array}{c}\text { Intern } \\
\text { al }\end{array}$} & $\begin{array}{c}\text { Penulisa } \\
n \\
\text { diameter }\end{array}$ & \multirow[t]{5}{*}{$\begin{array}{l}\text { Pemaha } \\
\text { man } \\
\text { masalah }\end{array}$} & Fakta & - & \multirow{9}{*}{$\begin{array}{c}\text { Intern } \\
\text { al }\end{array}$} & - \\
\hline & & Konse & $\sqrt{ }$ & & Diamete & & Konse & - & & - \\
\hline & & $\mathrm{p}$ & & & $\begin{array}{c}\text { r \& jari- } \\
\text { jari }\end{array}$ & & $\mathrm{p}$ & & & \\
\hline & & $\begin{array}{l}\text { Opera } \\
\text { si }\end{array}$ & - & & - & & $\begin{array}{l}\text { Opera } \\
\text { si }\end{array}$ & - & & - \\
\hline & & $\begin{array}{l}\text { Prinsi } \\
\mathrm{p}\end{array}$ & - & & - & & $\begin{array}{l}\text { Prinsi } \\
\mathrm{p}\end{array}$ & - & & - \\
\hline \multirow{4}{*}{ Sedang } & \multirow{4}{*}{$\begin{array}{l}\text { Merenca } \\
\text { nakan } \\
\text { pemecah } \\
\text { an } \\
\text { masalah }\end{array}$} & Fakta & $\sqrt{ }$ & & $\begin{array}{c}\text { Penulisa } \\
n \\
\text { diameter }\end{array}$ & $\begin{array}{l}\text { Merenca } \\
\text { nakan } \\
\text { pemecah }\end{array}$ & Fakta & - & & - \\
\hline & & $\begin{array}{l}\text { Konse } \\
\mathrm{p}\end{array}$ & $\sqrt{ }$ & & $\begin{array}{l}\text { Diamete } \\
\text { r \& jari- } \\
\text { jari }\end{array}$ & $\begin{array}{l}\text { an } \\
\text { masalah }\end{array}$ & $\begin{array}{l}\text { Konse } \\
\mathrm{p}\end{array}$ & $\sqrt{ }$ & & $\begin{array}{l}\text { Jarak } \\
\text { poros }\end{array}$ \\
\hline & & $\begin{array}{l}\text { Opera } \\
\text { si }\end{array}$ & - & & - & & $\begin{array}{l}\text { Opera } \\
\text { si }\end{array}$ & - & & - \\
\hline & & $\begin{array}{l}\text { Prinsi } \\
\mathrm{p}\end{array}$ & & & $\begin{array}{c}\text { Gspl, } \\
\text { keliling }\end{array}$ & & $\begin{array}{l}\text { Prinsi } \\
\mathrm{p}\end{array}$ & $\sqrt{ }$ & & $\begin{array}{l}\text { Gspl \& } \\
\text { Trigono }\end{array}$ \\
\hline
\end{tabular}


WAHANA

e-ISSN 2654-4954, p-ISSN 0853-4403

Volume 71, Nomor 2, 1 Desember 2019

\begin{tabular}{|c|c|c|c|c|c|c|c|c|c|c|}
\hline \multirow{12}{*}{$\begin{array}{c}\text { Kemam } \\
\text { puan }\end{array}$} & \multicolumn{10}{|c|}{ Perbedaan Gaya Kognitif } \\
\hline & \multicolumn{5}{|c|}{ Field Dependent } & \multicolumn{5}{|c|}{ Field Independent } \\
\hline & $\begin{array}{l}\text { Letak } \\
\text { kesalaha } \\
\mathrm{n} \text { pada } \\
\text { tahap }\end{array}$ & $\begin{array}{c}\text { Jenis } \\
\text { kesala } \\
\text { han }\end{array}$ & $\begin{array}{c}\text { Keterlaks } \\
\text { anaan }\end{array}$ & $\begin{array}{c}\text { Facto } \\
r \\
\text { penye } \\
\text { bab }\end{array}$ & $\begin{array}{c}\text { Alasan } \\
\text { kesalaha } \\
\text { n }\end{array}$ & $\begin{array}{c}\text { Letak } \\
\text { kesalaha } \\
\text { n }\end{array}$ & $\begin{array}{c}\text { Jenis } \\
\text { kesala } \\
\text { han }\end{array}$ & $\begin{array}{c}\text { Keterlaks } \\
\text { anaan }\end{array}$ & $\begin{array}{c}\text { Factor } \\
\text { Penye } \\
\text { bab }\end{array}$ & $\begin{array}{c}\text { Alasan } \\
\text { kesalaha } \\
\text { n }\end{array}$ \\
\hline & & & & & $\begin{array}{c}\text { lingkara } \\
\text { n \& } \\
\text { Trigono } \\
\text { metri }\end{array}$ & & & & & metri \\
\hline & \multirow{4}{*}{$\begin{array}{l}\text { Melaksa } \\
\text { nakan } \\
\text { rencana } \\
\text { pemecah } \\
\text { an } \\
\text { masalah }\end{array}$} & Fakta & $\sqrt{ }$ & & $\begin{array}{c}\text { Penulisa } \\
n \\
\text { diameter }\end{array}$ & $\begin{array}{l}\text { Melaksa } \\
\text { nakan } \\
\text { rencana }\end{array}$ & Fakta & - & & - \\
\hline & & $\begin{array}{l}\text { Konse } \\
\mathrm{p}\end{array}$ & & & $\begin{array}{c}\text { Diamete } \\
\text { r \& jari- } \\
\text { jari }\end{array}$ & $\begin{array}{l}\text { pemecah } \\
\text { an } \\
\text { masalah }\end{array}$ & $\begin{array}{l}\text { Konse } \\
\mathrm{p}\end{array}$ & - & & - \\
\hline & & $\begin{array}{l}\text { Opera } \\
\text { si }\end{array}$ & & & $\begin{array}{c}\text { Mencari } \\
\text { akar } \\
\text { kuadrat }\end{array}$ & & $\begin{array}{l}\text { Opera } \\
\text { si }\end{array}$ & - & & - \\
\hline & & $\begin{array}{l}\text { Prinsi } \\
\mathrm{p}\end{array}$ & & & $\begin{array}{c}\text { Gspl, } \\
\text { keliling } \\
\text { lingkara } \\
\text { n \& } \\
\text { Trigono } \\
\text { metri }\end{array}$ & & $\begin{array}{l}\text { Prinsi } \\
\mathrm{p}\end{array}$ & $\sqrt{ }$ & & $\begin{array}{c}\text { Gspl \& } \\
\text { Trigono } \\
\text { metri }\end{array}$ \\
\hline & \multirow{4}{*}{$\begin{array}{l}\text { Melihat } \\
\text { kembali } \\
\text { hasil } \\
\text { pemecah } \\
\text { an } \\
\text { masalah }\end{array}$} & Fakta & $\sqrt{ }$ & & $\begin{array}{c}\text { Penulisa } \\
n \\
\text { diameter }\end{array}$ & \multirow{4}{*}{$\begin{array}{l}\text { Melihat } \\
\text { kembali } \\
\text { hasil } \\
\text { pemecah } \\
\text { an } \\
\text { masalah }\end{array}$} & Fakta & - & & - \\
\hline & & $\begin{array}{l}\text { Konse } \\
\mathrm{p}\end{array}$ & & & $\begin{array}{c}\text { Diamete } \\
\text { r \& jari- } \\
\text { jari }\end{array}$ & & $\begin{array}{l}\text { Konse } \\
\mathrm{p}\end{array}$ & $\sqrt{ }$ & & $\begin{array}{l}\text { Jarak } \\
\text { poros }\end{array}$ \\
\hline & & $\begin{array}{l}\text { Opera } \\
\text { si }\end{array}$ & & & $\begin{array}{c}\text { Mencari } \\
\text { akar } \\
\text { kuadrat }\end{array}$ & & $\begin{array}{l}\text { Opera } \\
\text { si }\end{array}$ & - & & - \\
\hline & & $\begin{array}{l}\text { Prinsi } \\
\mathrm{p}\end{array}$ & & & $\begin{array}{c}\text { Gspl, } \\
\text { keliling } \\
\text { lingkara } \\
\text { n \& } \\
\text { Trigono } \\
\text { metri }\end{array}$ & & $\begin{array}{l}\text { Prinsi } \\
\mathrm{p}\end{array}$ & $\sqrt{ }$ & & $\begin{array}{c}\text { Gspl \& } \\
\text { Trigono } \\
\text { metri }\end{array}$ \\
\hline & \multirow[t]{4}{*}{$\begin{array}{l}\text { Pemaha } \\
\text { man } \\
\text { masalah }\end{array}$} & Fakta & $\sqrt{ }$ & & $\begin{array}{c}\text { Penulisa } \\
n \\
\text { diameter }\end{array}$ & \multirow[t]{4}{*}{$\begin{array}{l}\text { Pemaha } \\
\text { man } \\
\text { masalah }\end{array}$} & Fakta & $\sqrt{ }$ & & $\begin{array}{c}\text { Penulisa } \\
\text { n jari- } \\
\text { jari }\end{array}$ \\
\hline & & $\begin{array}{l}\text { Konse } \\
\mathrm{p}\end{array}$ & $\sqrt{ }$ & & $\begin{array}{c}\text { Jari-jari } \\
\text { dan } \\
\text { diameter }\end{array}$ & & $\begin{array}{l}\text { Konse } \\
\mathrm{p}\end{array}$ & - & & - \\
\hline & & $\begin{array}{l}\text { Opera } \\
\text { si }\end{array}$ & & & - & & $\begin{array}{l}\text { Opera } \\
\text { si }\end{array}$ & - & & - \\
\hline Rendah & & $\begin{array}{l}\text { Prinsi } \\
\mathrm{p}\end{array}$ & - & $\begin{array}{l}\text { Intern } \\
\text { al }\end{array}$ & - & & $\begin{array}{l}\text { Prinsi } \\
\mathrm{p}\end{array}$ & $\sqrt{ }$ & $\begin{array}{l}\text { Intern } \\
\text { al }\end{array}$ & $\begin{array}{c}\text { Gspl, } \\
\text { keliling } \\
\text { lingkara } \\
\mathrm{n} \& \\
\text { trigono }\end{array}$ \\
\hline
\end{tabular}


WAHANA

e-ISSN 2654-4954, p-ISSN 0853-4403

Volume 71, Nomor 2, 1 Desember 2019

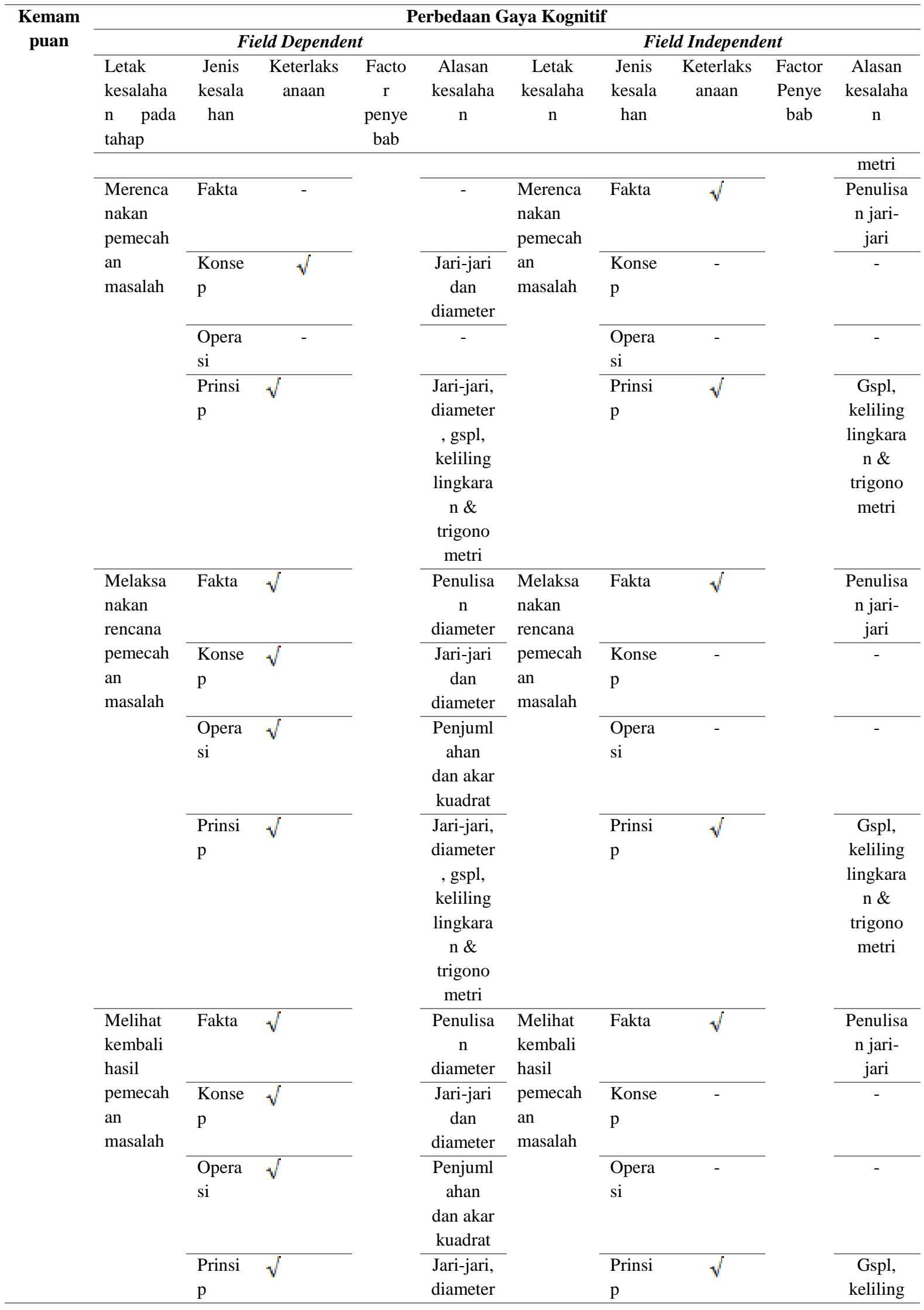




\begin{tabular}{|c|c|c|c|c|c|c|c|c|c|c|}
\hline \multirow{4}{*}{$\begin{array}{c}\text { Kemam } \\
\text { puan }\end{array}$} & \multicolumn{10}{|c|}{ Perbedaan Gaya Kognitif } \\
\hline & \multicolumn{5}{|c|}{ Field Dependent } & \multicolumn{5}{|c|}{ Field Independent } \\
\hline & $\begin{array}{l}\text { Letak } \\
\text { kesalaha } \\
\text { n pada } \\
\text { tahap }\end{array}$ & $\begin{array}{c}\text { Jenis } \\
\text { kesala } \\
\text { han }\end{array}$ & $\begin{array}{c}\text { Keterlaks } \\
\text { anaan }\end{array}$ & $\begin{array}{c}\text { Facto } \\
r \\
\text { penye } \\
\text { bab }\end{array}$ & $\begin{array}{c}\text { Alasan } \\
\text { kesalaha } \\
\text { n }\end{array}$ & $\begin{array}{c}\text { Letak } \\
\text { kesalaha } \\
\text { n }\end{array}$ & $\begin{array}{c}\text { Jenis } \\
\text { kesala } \\
\text { han }\end{array}$ & $\begin{array}{c}\text { Keterlaks } \\
\text { anaan }\end{array}$ & $\begin{array}{c}\text { Factor } \\
\text { Penye } \\
\text { bab }\end{array}$ & $\begin{array}{c}\text { Alasan } \\
\text { kesalaha } \\
\text { n }\end{array}$ \\
\hline & & & & & $\begin{array}{c}\text {, gspl, } \\
\text { keliling } \\
\text { lingkara } \\
\text { n \& } \\
\text { trigono } \\
\text { metri }\end{array}$ & & & & & $\begin{array}{c}\text { lingkara } \\
\mathrm{n} \& \\
\text { trigono } \\
\text { metri }\end{array}$ \\
\hline
\end{tabular}

Keterangan :

$-\quad=$ Tidak terlaksana

$\sqrt{ } \quad=$ Terlaksana

Gspl = garis singgung persekutuan luar

\subsection{Pembahasan}

Berdasarkan analisis dan hasil penelitian yang diperoleh, maka letak kesalahan subjek yang berkemampuan rendah dengan gaya kognitif field dependent dalam pemecahan masalah matematika trigonometri adalah terdapat pada semua tahap pemecahan masalah yaitu mulai memahami masalah, membuat rencana pemecahan masalah, melaksanakan rencana pemecahan masalah, sampai pada melihat kembali hasil pemecahan masalah. Sementara jenis kesalahan yang dilakukan Subjek berkemampuan rendah yang memiliki gaya kognitif field dependent adalah semua jenis kesalahan mulai dari kesalahan fakta, konsep, oprasi, dan prinsip yang menyebar pada semua tahap pemecahan masalah. Sementara factor penyebab terjadinya kesalahan secara umum adalah faktor internal yang diakibatkan oleh kemampuan intelektual, dan kondisi kognitif dari subjek.

Letak kesalahan dari Subjek yang berkemampuan rendah yang memiliki gaya kognitif field independent dalam pemecahan masalah matematika trigonometri adalah terdapat pada semua tahap pemecahan masalah yaitu mulai dari tahap memahami masalah, membuat rencana pemecahan masalah, melaksanakan rencana pemecahan masalah, sampai pada melihat kembali hasil pemecahan masalah. Jenis kesalahan yang dilakukan subjek berkemampuan rendah dengan gaya kognitif field independent adalah jenis kesalahan fakta dan prinsip yang menyebar pada semua tahap pemecahan masalah. Sementara factor penyebab terjadinya kesalahan secara umum adalah faktor internal yang diakibatkan oleh kemampuan intelektual, dan kondisi kognitif dari subjek.

Jika dibandingkan antara subjek berkemampuan rendah yang bergaya kognitif field dependent dengan subjek berkemampuan rendah yang bergaya kognitif field independent memiliki kesamaan dan perbedaan. Kesamaannya adalah sama-sama melakukan kesalahan pada semua tahap pemecahan masalah. Sementara perbedaanya adalah subjek berkemampuan rendah dengan gaya kognitif field independent hanya melakukan 2 jenis kesalahan, tetapi subjek yang berkemampuan rendah bergaya kognitif field dependent melakukan 4 jenis kesalahan sekaligus.

Letak kesalahan Subjek yang berkemampuan sedang dengan gaya kognitif field dependent dalam pemecahan masalah 
matematika Trigonometri adalah terdapat pada semua tahap pemecahan masalah yaitu mulai memahami masalah, membuat rencana pemecahan masalah, melaksanakan rencana pemecahan masalah, sampai pada melihat kembali hasil pemecahan masalah. Sementara jenis kesalahan yang dilakukan Subjek berkemampuan sedang yang memiliki gaya kognitif field dependent adalah semua jenis kesalahan mulai dari kesalahan fakta, konsep, operasi, dan prinsip yang menyebar pada semua tahap pemecahan masalah. Sementara faktor penyebab terjadinya kesalahan secara umum adalah faktor internal yang diakibatkan oleh kemampuan intelektual, dan kondisi kognitif dari subjek.

Letak kesalahan dari Subjek yang berkemampuan sedang yang memiliki gaya kognitif field independent dalam pemecahan masalah matematika trigonometri adalah terdapat pada tiga tahap pemecahan masalah yaitu membuat rencana pemecahan masalah, melaksanakan rencana pemecahan masalah, sampai pada melihat kembali hasil pemecahan masalah. Subjek yang berkemampuan sedang yang memiliki gaya kognitif field independent tidak melakukan kesalahan pada tahap memahami masalah. Jenis kesalahan yang dilakukan subjek berkemampuan sedang dengan gaya kognitif field independent adalah jenis kesalahan konsep dan prinsip yang menyebar pada semua tahap membuat rencana pemecahan masalah, melaksanakan rencana pemecahan masalah, dan melihat kembali hasil pemecahan masalah. Sementara factor penyebab terjadinya kesalahan secara umum adalah faktor internal yang diakibatkan oleh kemampuan intelektual, dan kondisi kognitif dari subjek.

Jika dibandingkan antara subjek berkemampuan sedang yang bergaya kognitif field dependent dengan subjek berkemampuan sedang yang bergaya kognitif field independent memiliki perbedaan pada letak dan jenis kesalahan yang dilakukannya. Letak kesalahan subjek berkemampuan sedang dengan gaya kognitif field independent terdapat pada 3 tahap pemecahan masalah yaitu tahap membuat rencana pemecahan masalah, melaksanakan rencana pemecahan masalah, melihat kembali hasil pemecahan masalah. Lain hal nya dengan letak kesalahan Subjek yang berkemampuan sedang bergaya kognitif field dependent yaitu terletak pada semua tahap pemecahan masalah yang terdiri dari 4 tahap yaitu mulai dari memahami masalah, membuat rencana pemecahan masalah, melaksankan rencana pemecahan masalah sampai pada melihat kembali hasil pemecahan masalah.

Sementara jenis kesalahan Subjek berkemampuan sedang dengan gaya kognitif field dependent adalah semua jenis kesalahan yaitu kesalahan fakta, konsep, oprasi, dan prinsip. Jenis-jenis kesalahan tersebut menyebar pada semua tahap pemecahan masalah. Lain hal nya dengan jenis kesalahan Subjek yang berkemampuan sedang bergaya kognitif field independent hanya melakukan 2 jenis kesalahan yaitu kesalahan konsep dan prinsip yang menyebar hanya pada setiap tahap pemecahan masalah kecuali tahap memahami masalah.

Letak kesalahan Subjek yang berkemampuan tinggi dengan gaya kognitif field dependent dalam pemecahan masalah matematika Trigonometri adalah terdapat pada 3 tahap pemecahan masalah yaitu membuat rencana pemecahan masalah, melaksanakan rencana pemecahan masalah, dan melihat kembali hasil pemecahan masalah. Sementara jenis kesalahan yang dilakukan Subjek berkemampuan tinggi yang memiliki gaya kognitif field dependent adalah jenis kesalahan prinsip yang menyebar pada 3 tahap pemecahan masalah, 
yaitu membuat rencana pemecahan masalah, melaksanakan rencana pemecahan masalah, dan melihat kembali hasil pemecahan masalah. Sementara faktor penyebab terjadinya kesalahan secara umum adalah faktor internal yang diakibatkan oleh kemampuan intelektual, dan kondisi kognitif dari Subjek.

Subjek berkemampuan tinggi dengan gaya kognitif field independent tidak melakukan kesalahan pada semau tahap pemecahan masalah trigonometri. Adapun faktor penyebab tidak terjadinya kesalahan secara umum adalah faktor internal yang diakibatkan oleh tingginya kemampuan intelektual, dan kondisi kognitif dari Subjek.

Jika dibandingkan antara subjek berkemampuan tinggi yang bergaya kognitif field dependent dengan subjek berkemampuan tinggi yang bergaya kognitif field independent memiliki perbedaan pada letak dan jenis kesalahan yang dilakukannya. Letak kesalahan subjek berkemampuan tinggi dengan gaya kognitif field dependent terdapat pada 3 tahap pemecahan masalah yaitu tahap membuat rencana pemecahan masalah, melaksanakan rencana pemecahan masalah, melihat kembali hasil pemecahan masalah. Lain hal nya dengan Subjek yang berkemampuan tinggi bergaya kognitif field independent tidak melakukan kesalahan dalam pemecahan masalah trigonometri.

Berdasarkan dari hasil penelitian, analisis, dan pembahasan, maka temuan dari penelitian ini adalah gaya kognitif mempengaruhi proses dan hasil pemecahan masalah trigonometri dari subjek yang berkemampuan rendah, sedang, dan tinggi. Subjek bergaya kognitif field dependent lebih banyak melakukan kesalahan (baik letak kesalahan maupun jenis kesalahan), daripada Subjek yang bergaya kognitif field independent. Hal ini sejalan dengan hasil penelitian yang dilakukano oleh Andi sukriani, Utomo, astunisyah, dan Tatag bahwa gaya kognitif (FI dan FD) yang dimiliki oleh siswa SMA mempengaruhi hasil pemecahan masalah matematika. Namun dalam penelitian tersebut mereka tidak melihat letak, jenis, serta factor penyebab kesalahan yang dilakukan oleh siswa dalam pemecahan masalah matematika.

\section{KESIMPULAN}

Kesalahan yang dilakukan oleh Siswa SMK Pemesinan yang berkemampuan rendah dan bergaya kognitif field dependent lebih banyak daripada Siswa SMK Pemesinan yang berkemampuan rendah dan bergaya kognitif field independent ditinjau dari jenis kesalahannya. Kesalahan yang dilakukan oleh Siswa SMK Pemesinan yang berkemampuan sedang dan bergaya kognitif field dependent lebih banyak daripada Siswa SMK Pemesinan yang berkemampuan sedang dan bergaya kognitif field independent ditinjau dari letak dan jenis kesalahannya. Kesalahan yang dilakukan oleh Siswa SMK Pemesinan yang berkemampuan tinggi dan bergaya kognitif field dependent lebih banyak daripada Siswa SMK Pemesinan yang berkemampuan tinggi dan bergaya kognitif field independent, karena siswa yang berkemampuan tinggi dan bergaya kognitif field independent tidak melakukan kesalahan sementara Siswa yang berkemampuan tinggi dan bergaya kognitif field dependent melakukan sedikit kesalahan ditinjau dari letak dan jenis kesalahannya.

Sementara faktor penyebab terjadinya kesalahan yang dilakukan oleh Siswa SMK Pemesinan baik yang berkemampuan tinggi, sedang, atupun rendah dan bergaya kognitif field dependent ataupun field independent secara umum adalah faktor internal yang diakibatkan oleh kemampuan intelektual, dan kondisi kognitif dari Subjek. 


\section{REFERENSI}

1. Acharya, Ms. Chandrama. Studens Learning Style and Their Implication for Teachers. Center for Development of Teaching and Learning, September 2002 Vol. 5 No. 6.

2. Angeli, Charoula \& Valanides, N. Using educational data mining methods to assess field-dependent and fieldindependent learners' complex problem solving. Education Tech Research Dev (2013) 61, pp. 521-548. DOI 10.1007/s11423-013-9298-1

3. Adibifar, S. \& Nosratinia, M. The Effect of Teaching Metacognitive Strategies on Field Dependent and Independent Learners' Writing. Published by Elsevier Ltd. Procedia - Social and Behavioral Sciences 98 (2014), pp. 1390 $-1399$.

4. Ausubel, D.P. Educational PsychologyA cognitive view. New York: Holt, Rinehart and Winston, Inc, (1968).

5. Astunnisyah, Budiyono, Isnandar, S., The Comparison of Learning Model Viewed from The Student Cognitive Style. The 4th International Conference on Research, Implementation, and Education of Mathematics and Science (4th ICRIEMS). AIP Conference Proceedings 1868, edited by (America Institute of Physics, 2017), pp. 050003-1 - 050003-6, doi: 10.1063/1.4995130.

6. Balwin, James, J. The Interaction of Field Dependence and Field Independence with Method of Instruction in Mathematics. England: Hofstra University, (1977).

7. Brown, H. D. Principles of language learning and teaching. Indiana: Prentice Hall, (1993).
8. Cooney, T.J., Davis, E.J.,Henderson, K.B. Dynamics of Teaching Secondary School Mathematics, Boston, Houghton Mifllin Company, (1975).

9. Depdikbud. 2014. Permendikbud Nomor 70 Tahun 2013 Tentang Sekolah Menengah Kejuruan. Jakarta : 2014

10. Kemendikbud. Panduan Pelatihan Guru Matematika SMA/SMK dalam Penerapan Kurikulum 2013. Jakarta: Kemendikbud, (2014).

11. Kirkley, J. Principle for Teaching Problem Solving, Technical Paper, Plato Learning Inc, (2003).

12. Polya, G. How to Solve It. Second Edition. Princeton: University Press Princeton, (1973).

13. Slameto. Belajar dan Faktor-Faktor yang Mempengaruhinya. Revised Edition. Jakarta: PT Rineka Cipta, (2003).

14. Soedjadi, R. Kiat Pendidikan Matematika Di Indonesia. Konstatasi Keadaan Masa Kini Menuju Harapan Masa Depan. Jakarta: Direktorat Jenderal Pendidikan Tinggi, Departemen pendidikan Nasional, (2000).

15. Sukriani, A., Juniati, D., Tatag, Y.E.S. Strategic Competence of Senior Secondary School Students in Solving Mathematics Problem Based on Cognitive Style. The 4th International Conference on Research, Implementation, and Education of Mathematics and Science (4th ICRIEMS). AIP Conference Proceedings 1868, edited by (America Institute of Physics, 2017), pp. 050009-1 - 0500096. DOI: $10.1063 / 1.4995136$.

16. Tatag, Y.E.S. et al. An Investigation of Secondary Teachers' Understanding and Belief on Mathematical Problem Solving. Journal of Physics: Conference series 693(2016). IOP 
Publishing.

DOI: $10.1088 / 1742-$ 6596/693/1/012015.

17. Utomo, E. S., Juniati, D., Tatag, Y.E.S. Mathematical Visualization Process of Junior High School Students in Solving a Contextual Problem Based on Cognitive Style. The 4th International Conference on Research, Implementation, and Education of Mathematics and Science (4th ICRIEMS). AIP Conference Proceedings 1868, edited by (America Institute of
Physics, 2017), pp. 050011-1-05001114; doi: 10.1063/1.4995138.

18. Witkin, H., A, Oltman, P., K., Raskin, E., \& Karp, S., A Manual for the Group Embedded Figures Test, Palo Alto, CA: Consulting Psikology Prees, (1971).

19. Witkin, H., A., Moore, C., A., Goodenough, D., R., \& Cox, P., W., (1977). Field Dependent \& Field Independent Cognitive Style and their Educational Implicationc. Review of Education Researcch Winter. Vol.47. No.1 Page 1-64. 